\title{
Productivity, Wages, Profits, and Exchange Rates in an Era of Globalization
}

\author{
Produtividade, salários, lucros e taxa de cambio \\ em uma era de globalização
}

\begin{abstract}
Hartmut Elsenhans*
RESUMO: As corridas mundiais de desvalorização levam à globalização da renda, em vez do lucro e da autonomia da sociedade civil. Esse padrão específico da globalização de hoje segue sérias tendências subconsumistas, uma vez que a autossuficiência na produção de bens salariais é alcançada em economias com um produto marginal muito baixo do trabalho na agricultura e desemprego estrutural que desestimula todo o trabalho. Da mesma forma, no século XIX, a globalização intensiva foi caracterizada por tendências de pleno emprego, aumento dos salários reais e expansão do estado de bem-estar. Um retorno a esse modelo de comboio da globalização é possível por meio da marginalidade, reduzindo as políticas de desenvolvimento para elevar os padrões dos pobres no sul.

PALAVRAS-CHAVE: Produtividade; salários; lucros; taxa de câmbio.

ABSTRACT: Worldwide devaluation races lead to the globalization of rent instead of profit and autonomy of civil society. This specific pattern of today's globalization goes with serious underconsumptionist tendencies as self-sufficiency in wage goods production is achieved in economies with a very low marginal product of labour in agriculture and structural unemployment which disempowers all labour. The 19th century likewise intensive globalization was characterized by full employment tendencies, rising real wages and an expansion of the welfare state. A return to such a convoy model of globalization is possible through marginality reducing development policies for uplifting the poor in the South.

KEYWORDS: Productivity; wages; prolits; exchange rate.

JEL Classification: F31; J3.
\end{abstract}

Globalization - the reduction of transaction costs for the flow of goods and services, investment and short-term capital across national borders - is said to deprive the "nation-state" of its capacity to engage in economic intervention except

\footnotetext{
* Professor do Departamento de Economia da Universidade Federal Fluminense. E-mail: elsenhans@ yahoo.de; ORCID 0000-0002-1029-6621.
} 
where this intervention increases the economy's competitiveness. The "competition state" is said to replace the welfare state. ${ }^{1}$

The great majority of the population of the industrialized world feels uneasy about globalization or even fears it. In contrast, in the other great period of globalization, the worldwide expansion of capital under the banner of imperialism, a "revolutionary" labor movement not only submitted to the demands of capital, but even considered imperialism to be a civilizational process, ${ }^{2}$ or viewed the "latest stage of imperialism" as preparing the way for the transition to socialism. ${ }^{3}$ Thus, the reactions to globalization in two different historical periods have been different, notwithstanding the current globalization drive with respect to trade and long-term investment only in the 1980s regained a comparable level to the period before First World War. ${ }^{4}$

The much larger short-term capital movements on financial markets are not proof of a high degree of internationalization, but, rather, of a low one. ${ }^{5}$ Most international financial transactions today are short-term and based on predictions of movements in foreign exchange rates. In a world economy where national currencies were linked to the international costs of production of a highly uniform commodity with nearly no transaction costs for its trade, such as gold, substantial ex-

1 Cerny, Philip G. "Globalization and the Erosion of Democracy", in European Journal of Political Research, 36, 1 (August 1999), p. 16. Cerny, Philip G. "The Paradoxes of the Competition State. The Dynamics of Political Globalization”, in Government and Opposition, 32, 2 (1997), pp. 251-74. Hirsch, Joachim "Nation-state, International Regulation and the Question of Democracy", in Review of International Political Economy, 2, 2 (1995) pp. 267-84.

${ }^{2}$ Schorske, Carl E. German Social Democracy, 1905-1917. The Great Schism (Cambridge, Mass.: Harvard University Press, 1965), p. 79.

${ }^{3}$ Cf. the title of Lenin's analysis: Lenin, Vladimir Iljitch: Imperialism. The Highest Stage of Capitalism. A Popular Outline (Moscow: Progress Publishers, 1964).

${ }^{4}$ Verdier, Daniel "Domestic Responses to Capital Market Internationalization under the Gold Standard", in International Organization, 52, 1 (Winter 1998), pp. 43ff. UNCTAD: World Investment Report 1994. Transnational Corporations, Employment and the Workplace (New York; Geneva: United Nations, 1994), pp. 120-1. Theurl, Theresia "Globalisierung als Selektionsprozeß ordnungspolitischer Paradigmen", in Berg, Hartmut (ed.) Globalisierung der Wirtschaft: Ursachen-Formen-Konsequenzen (Berlin: Duncker \& Humblot, 1999), p. 26. Bairoch, Paul "Globalization, Myths and Realities: One Century of External Trade and Foreign Investment", in Boyer, Robert; Drache, Daniel (eds.) States Against Markets. The Limits of Globalization (London: Routledge, 1996), pp. 173-92. Irwin; Douglas A. "The United States in a New Global Economy? A Century's Perspective”, in American Economic Review, 86, 2 (March 1996), pp. 41-4. Bergeljik, Peter; Mensik, Nico W. "Measuring Globalization”, in Journal of World Trade, 31, 3 (June 1997), p. 166. Bovenberg, A. Lans; Gordon, Roger H. "Why Is Capital so Immobile Internationally? Possible Explanations and Implications for Capital Income Taxation", in American Economic Review, 86, 5 (December 1996), pp. 1057-76. Williamson, Jeffrey G. "Globalization, Convergence and History”, in Journal of Economic History, 56, 2 (June 1996), pp. 277-306.

${ }^{5}$ Kregel, Jan A. "Capital Flows: Globalization of Production and Financing Development", in UNCTAD Review (1994), pp. 23-38. Helleiner, Eric State and the Reemergence of Global Finance. From Bretton Woods to the 1990s (Ithaca, N.Y. et al.: Cornell University Press, 1994). Epstein, Gerald "International Capital Mobility and the Scope for National Economic Management", in Boyer, Robert; Drache, Daniel (eds.) States Against Markets. The Limits of Globalization (London: Routledge, 1996), pp. 211-24. 
change rate fluctuations would not occur; if the exchange rate of a currency was too low, the currency would be bought up and converted into gold at its fixed rate. The growth of financial markets is therefore linked to the emergence of Keynesian interventionist monetary policies.

With the end of the gold standard, currencies are basically pegged to the overall productivity of their respective economies in tradables and non-tradables, the latter being an increasingly important category of mass consumption because of the rising consumption of services and, in some cases, of housing. The higher the share of non-tradables in the consumption of labor which produces tradables, the greater the possibilities of indirectly subsidizing labor (making it cheaper) in the export sector through the exchange rate. A low exchange rate enables cheapening exports even to levels where export workers can no longer buy their wage goods from the world market (provided that the local non-tradable-producing sector supplies these goods). With the gold standard, this type of subsidization requires a fall in the nominal price of non-tradables - which is much more difficult to achieve, especially if the wage goods produced are only artificially non-tradable such as food. An exchange rate based on average productivity makes subsidizing the export sector relatively easy, whereas an exchange rate based on an internationally tradable commodity allows less such subsidies.

Globalization is also limited in the sphere of international communications. In the late 1940s and the 1950s, international communication was characterized by a globally shared vision of market failure, leading to the conclusion that state intervention into the economy was inevitable. With the defeat of fascism, it became clear that such interventionism required democratic legitimacy. The colonial powers were forced to withdraw, as they were neither elected nor able to present themselves as trustees in the interests of the populations in the territories they administered. ${ }^{6}$ In those days, a local uprising not only rapidly caught worldwide attention, but often triggered off uprisings elsewhere. No colonial power was able to use its full capacity of repression against such movements because of the risk of facing worldwide condemnation, with consequences not only for its international reputation but also for the domestic political process. Only dictatorships in small countries, such as Portugal, which were not integrated in the world system, could continue not to pay attention to globally accepted values, and this only for a limited period of time. Yet even the colonial diehards here, at least the more intelligent factions, eventually had to admit the necessity of democratic principles, i.e., decolonization. ${ }^{7}$

\footnotetext{
${ }^{6}$ Furedi, Frank "Creating a Breathing Space: The Political Management of Colonial Emergencies", in Journal of Imperial and Commonwealth History, 21, 3 (September 1993), p. 91. Elsenhans, Hartmut, La guerre d'Algérie 1954-1962. La transition d'une France à une autre. Le passage de la IVe à la Ve République (Paris: Publisud, 2000), pp. 344-51.

${ }^{7}$ Assunção, Pedro "Portugal und Afrika: Die neokolonialistische Unmöglichkeit”, in Verfassung und Recht in Übersee, 20, 3 (July/September 1987), pp. 343-56.
} 
Despite the manifold encroachments on national sovereignty, the injunctions of international financial institutions against debtor nations are rarely mandatory nowadays: no country, in the present framework of structural adjustment programs, faces punishment if it defaults on its debts, as was the case before 1914 (e.g., management of the Ottoman debt by a committee of representatives of the creditor nations, not to mention the military occupation of debtor countries for the sake of assuring good financial management, as was the case in Central America and the Caribbean). Fujimori's Peru has demonstrated that even a small country, which is not looking for fresh money and new loans, can relatively neglect financial markets, in contrast to "middle" powers in Asia, Africa and Latin America before 1914.

It is not globalization itself that constitutes the challenge, but its specific conditions and the patterns it has followed. This qualification implies that the problem of how to best manage the process is of greater importance than the necessity of resisting it.

There are two hypotheses with respect to these conditions and patterns. In a traditional, nation-state-oriented approach, focused on the relations between economics and politics, the territorial limitation of the "nation"-state is deplored, since no institutions have emerged - either at international, or regional level — which are capable of setting and enforcing binding rules and thus creating the framework for economic activity. This approach is largely adopted in the analysis of the protection of public goods at the global level, initially with regard to environmental issues, and increasingly with respect to human rights issues at the international level. It implies either resisting globalization, or, alternatively, extending it to the political sphere by creating international quasi-state institutions. Yet, the second alternative is not realistic in a global set-up where no one is really willing to risk the dangers of a world state. ${ }^{8}$

The Keynesian perspective is quite different. The state is only an actor insofar as the market fails. It is not primarily the institution of the state but the current state of the economy which largely influences outcomes. The economy may, however, be caught in a low-production trap, where low physical investment leads to low levels of employment and low effective demand, despite stagnating real wages. In this case, effective demand decreases even further in relation to productive potential, with further tendencies to low levels of economic activity. Keynes argued that monetary and fiscal policy would constitute instruments for overcoming shortterm imbalances on the labor market, but that their usefulness would be otherwise limited. Planned savings may, however, rise because there is a long-term social problem of distribution linked to the unemployment/low-level-demand trap. The propensity to save being dependent on the level of household incomes and on expectations of future developments, the present long-term economic crisis and labor's

\footnotetext{
${ }^{8}$ Cf. the discussion in Albert, Matthias; Brock, Lothar, Debordering the World of States. New Spaces in International Relations. Working Paper 2 (Darmstadt, Frankfurt am Main: World Society Research Group, 1995), p. 95.
} 
loss of bargaining power contribute to a decline in effective demand, which further disempowers labor.

The improbability that the invisible hand lead to full employment increases as a result of the application of the Keynesian mechanism itself. Fiscal and monetary policy are possible because the creation of book money does not imply scarcity of resources in the future (as claimed by the theory of rational expectations), given the assumption that the factors of production employed would have otherwise been idle and that their employment through additional financial resources leads to productivity increases. The additional production which results from the upturn of the economy would in this case constitute the physical counterpart to these additional financial resources. On the other hand, book money may also appear on financial markets as savings without necessarily commanding additional factors of production. Thus the creation of book money implies the further necessity of intervening in the economic process. Hayek hinted at this problem early on by arguing that an upswing of the economy through the creation of additional financial resources already implies a future downswing. ${ }^{9}$

\section{ECONOMIC EFFICIENCY OF CAPITALISTS MAKES FULL EMPLOYMENT THROUGH CAPITAL ACCUMULATION NOT GUARANTEED}

The process of economic growth is associated with rising mass incomes. ${ }^{10}$ This empirical fact is not a point of controversy between Keynesian and neoclassical economics. Real wages have grown since the beginning of capitalism, with the exception of major political crises, such as the Napoleonic Wars. ${ }^{11}$ In the early stages of industrialization real wages normally grew at a slower pace than industrial productivity because of the slow growth of productivity in agriculture and the

\footnotetext{
${ }^{9}$ Hayek, Friedrich A. von: Monetary Theory and the Trade Cycle (New York: Augustus M. Kelley, 1966), pp. 140ff. Hayek, Friedrich A. The Pure Theory of Capital (Chicago, Ill.: University of Chicago Press, 1941), p. 34.

${ }^{10}$ The various implications of the argument that capitalist growth is led by mass demand cannot be intensively dealt with here. Cf. Elsenhans, Hartmut "Rising Mass Incomes as a Condition of Capitalist Growth: Implications for the World Economy", in International Organization, 37, 1 (Winter 1983), pp. 1-38. Elsenhans, Hartmut "Égalité et développement. L'expérience européenne et le monde sousdéveloppé d'aujourd'hui”, in Cultures et développement, 15, 2 (1983), pp. 187-216.

${ }^{11}$ Crafts, Nicholas F. R. "English Workers' Real Wages During the Industrial Revolution: Some Remaining Problems", in Journal of Economic History, 45, 1 (June 1985), p. 144. Brown, John C. "The Condition of England and the Standard of Living: Cotton Textiles in the Northwest, 1806-1850", in Journal of Economic History, 50, 3 (September 1990), p. 591. Mokyr, Joel "Is there Still Life in the Pessimist Case? Consumption During the Industrial Revolution, 1790-1850", in Journal of Economic History, 48, 1 (March 1988), p. 77. Fisher, Douglas, The Industrial Revolution. A Macroeconomic Interpretation (New York, 1992), p. 72. Shammas, Carole, The Pre-industrial Consumer in England and America (Oxford: Clarendon, 1990), p. 228. Borsay, Peter, The English Urban Renaissance. Culture and Society in the Provincial Town 1660-1770 (Oxford: Clarendon, 1989), p. 228.
} 
high share of agriculture in the supply of wage goods (food) at low levels of real wages. ${ }^{12}$ But for neoclassical analysis, wages follow productivity. Rising real wages do not launch economic growth but, rather, limit it. At low wages and high profits, investment is high, so that the growth rate rises. Higher investment increases employment. Labor becomes scarce and enterprises raise wages in order to attract labor until the wage rate reaches the level of marginal earnings which can be realized on the market.

Keynesians doubt that financial resources are automatically transformed into investment, because these resources can also be kept as monetary reserves without contributing to real demand. The strategic character of various elements of final demand in raising investment (and employment) will be difficult to determine, however, and even controversial among Keynesians. Most Keynesians would insist on the possibility of returning to full employment via a short or medium-term increase in spending by enterprises and/or the state. Once the economy returns to full employment the neoclassical mechanism of bringing consumption and demand in line via scarcity-determined wage increases would be relaunched. Full employment with the implied rise of consumption demand may, however, not occur within a reasonable time period, so that investment does not trigger off the mechanism of demand expansion implied in the neoclassical theory of the wage drift.

In fact, additional investments are a limited solution to the dilemma because capitalism's microeconomic efficiency is so great that the system is unable to absorb unlimited shares of its total net product in the form of investment.

This problem was first dealt with by Bortkiewicz ${ }^{13}$ in his analysis of Marx's law of the tendential fall of the rate of profit. It was reformulated on the basis of synchronized labor costs by Okishio ${ }^{14}$ with the same results, ${ }^{15}$ and since then has

12 Clark, Gregory; Huberman, Michael; Lindez, Peter H. “A British Food Puzzle, 1770-1850”, in Economic History Review, 48, 2 (May 1995), p. 234. Shammas, Carole "Food Expenditures and Economic Well-being in Early Modern England”, in Journal of Economic History, 43, 1 (March 1983), p. 91. Horrel, Sara; Humphries, Jane "Old Questions, New Data, and Alternative Living Standards in the Industrial Revolution”, in Journal of Economic History, 52, 4 (December 1992), p. 872. Horrell, Sara "Home Demand and British Industrialization", in Journal of Economic History, 56, 3 (September 1996), p. 561. Tilly, Charles "Food Supply and Public Order in Modern Europe", in Tilly, Charles: The Formation of National States in Western Europe (Princeton, N.J.: Princeton University Press, 1975), p. 405. Hobsbawm, Eric J. “The British Standard of Living, 1790-1850”, in Economic History Review, 10, 1 (1957), p. 59.

${ }^{13}$ Bortkiewicz, L. von "Wertrechnung und Preisrechnung im Marxschen System, 3. Teil”, in Archiv für Sozialwissenschaft und Sozialpolitik, 25, 2 (1907), pp. 455-65.

14 Okishio, Nobuo "Technical Changes and the Rate of Profit”, in Kobe University Economic Review, 7 (1961), pp. 85-90.

${ }^{15}$ Cf. Roemer, John E. "Continuing Controversy on the Falling Rate of Profit: Fixed Capital and Other Issues”, in Cambridge Journal of Economics, 3, 4 (December 1979), pp. 379-98. Bowles, Samuel "Technical Change and the Profit Rate: A Simple Proof of the Okishio Theorem", in Cambridge Journal of Economics, 5, 2 (1981), pp. 183-86. Hunt, Ian "An Obituary or a New Life for the Tendency of the Rate of Profit to Fall”, in Review of Radical Political Economics, 15, 1 (Spring 1983), pp. 131-48. Van 
only been refuted on the basis of very special conditions. ${ }^{16}$ Bortkiewicz showed that as long as real wages remain constant no capitalist entrepreneur can competitively introduce a technology if it does not raise the rate of profit. This argument about the microeconomic behavior of capitalists does not, however, exclude the possibility that the profit rate declines if real wages rise and lead to the introduction of new products which do not directly compete with existing ones. The new product satisfies new needs (and this implies that consumption increases in real terms). The implied Bortkiewicz criterion, that capitalists do not spend on technologies where the profit rate is lower than average, is satisfied if the price of new products allows a profit rate equal or superior to the profit rate in old products. This may be achieved even if capital intensity increases. There is no need for any measurable physical productivity increase in the production of the new product, ${ }^{17}$ but only the readiness of the consumer to pay a high enough price. New products, which are produced in capital-intensive ways, may allow for Marx's rise of the organic composition of capital to occur. ${ }^{18}$ The possibility of rising real wages implies the possibility of capital accumulation proceeding more rapidly than production. Capitalist growth on the basis of wage increases lower than productivity increases ${ }^{19}$ and

Parijs, Philippe "The Falling Rate of Profit Theory of Crisis. A Rational Reconstruction by Way of Obituary", in Review of Radical Political Economics, 12, 1 (Spring 1980), pp. 1-17.

${ }^{16}$ Critics insisted on the possibility of a falling profit rate in the case of joint-production of goods: Funke, Michael "Technikwahl und Profitrate. Ein kritischer Überblick über die augenblickliche Diskussion zum Gesetz des tendenziellen Falls der Profitrate”, in Zeitschrift für Wirtschafts- und Sozialwissenschaften, 104, 3 (1984), pp 307-25. Salvadori, Neri "Falling Rate of Profit With a Constant Real Wage - An Example”, in Cambridge Journal of Economics, 5, 1 (May 1981), pp. 57-66. Bidard, Christian "The Falling Rate of Profit and Joint Production", in Cambridge Journal of Economics, 12, 3 (September 1988), pp. 255-360. Renten, Geert "Accumulation of Capital and the Foundation of the Tendency of the Rate of Profit to Fall”, in Cambridge Journal of Economics, 15, 1 (March 1991), p. 87, neglects revalorization of capital through technical progress. Schutz, Eric "Non-Produced Inputs, Differential Profit Rates and the Okishio Theorem”, in Review of Radical Political Economics, 19, 2 (Summer 1987), pp. 4360 , insists on declining productivity due to natural resources, but then the process is not caused by capital accumulation. Armstrong, Philip; Glyn, Andrew "The Law of the Falling Rate of Profit and Oligopoly: A Comment on Shaikh", in Cambridge Journal of Economics, 4, 1 (March 1980), p. 67 and Scott, C.V. "International Capital and the Oil-Producing States in Africa. An Analysis of Angola, Nigeria and Algeria", in Journal of Developing Societies, 8, 2 (1992), pp. 179-93, introduce imperfect competition and lack of correct technology assessment. Kliman, Andrew J. "The Okishio Theorem: An Obituary", in Review of Radical Political Economics, 29, 3 (Summer 1997), p. 46, introduces false expectations without mentioning that this would lead to revalorization of capital.

${ }^{17}$ Indeed, productivity in the production of different products can be compared only by means of prices.

${ }^{18}$ Elsenhans, Hartmut "Globalization in a Labourist Keynesian Approach”, in Journal of Social Studies, forthcoming.

${ }^{19}$ We assume only two types of income, wages and net profits, where all net profits are reinvested. Ifwages stagnate, profits have to increase more rapidly than net income. In the case of productivity increases in line with the increase of available resources for investment, growth is explosive. The model is presented in detail in: Elsenhans, Hartmut "Rent, State and the Market: The Political Economy of the Transition to Self-sustained Capitalism”, in Pakistan Development Review, 33, 4 (December 1994), pp. 422-6. Elsenhans, Hartmut "Überwindung von Marginalität als Gegenstand der Armutsbekämpfung" 
increases in investment higher than productivity increases ultimately has to lead to a decline in the profit rate.

This decline of the profit rate appears to be the result of a decline in the rate of technical innovation. Neoclassical thinking can be saved if, in addition to the old factors of production - capital and labor - new factors of production - technologies, skills, human capital - are added..$^{20} \mathrm{New}$ endogenous growth theory, in essence, explores these new factors of production. These additional factors usually have one characteristic in common: they are the unintentional outcome of activities financed by non-enterprise sources (such as households or the state) or the result of joint-production processes, so that their cost does not reduce profit. If the creation of these additional factors of production is financed at the cost of capital, their production is cost effective only if capitalists are less able to forecast future developments in the requirements of technical progress than the non-capitalist promoters of these additional factors. Capitalists would otherwise prefer to spend their own resources on a more efficiently organized technical innovation system, which is not necessarily owned by individual enterprises. Business associations, for instance, may be called to coordinate innovation.

A given capitalist set-up for promoting innovation may be less efficient than another. The consequence of this inefficiency is the decline of the less innovative setup, and perhaps its future specialization on less dynamic branches.

The theory of endogenous growth ${ }^{21}$ explains the stability of the capital-output

in Schäfer, Hans Bernd (ed.): Bevölkerungsdynamik und Grundbedürfnisse in Entwicklungsländern (Berlin: Duncker \& Humblot, 1995), pp. 194-204.

${ }^{20}$ Becker, Gary S. Human Capital. A Theoretical and Empirical Analysis with Special References to Education (New York; London: Columbia University Press, 1964). Denison, Edward F. Why Growth Rates Differ (Washington: Brookings Institution, 1967). Faxen, Karl-Olof "Disembodied Technical Progress: Does Employee Participation in Decision Making Contribute to Change and Growth?", in American Economic Review, 68, 2 (May 1978), pp. 131-4. Lall, Sanjaya "Technical Effort and Disembodied Technology Exports: An Econometric Analysis of Inter-Industry Variations in India”, in World Development, 11, 6 (1983), pp. 527-35.

${ }^{21}$ Romer, Paul M. "The Origins of Endogenous Growth”, in Journal of Economic Perspectives, 8, 1 (1994), pp. 3-22. Romer, Paul M. "Growth Based on Increasing Returns Due to Specialization”, in American Economic Review, 77, 2 (1987), pp. 56-62. Romer, Paul M. "Increasing Returns and Longterm Growth", in Journal of Political Economy, 94, 2 (September/October 1986), pp. 1.002-37. Romer, Paul M. "Endogenous Technological Change”, in Journal of Political Economy, 98 (1990), pp. 71-102. Pack, Howard "Endogenous Growth Theory: Intellectual Appeal and Empirical Shortcoming", in Journal of Economic Perspectives, 8, 1 (Winter 1994), pp. 55-72. Segerstrom, P. "Innovation, Imitation and Economic Growth”, in Journal of Political Economy, 99, 4 (1991), pp. 807-27. Paqué, Karl Heinz "Technologie, Wissen und Wirtschaftspolitik - Zur Rolle des Staates in Theorien des Endogenen Wachstums", in Die Weltwirtschaft, 3 (1995), pp. 237-53. Klundert, Theo van; Meijdam, Lex "Endogenous Growth and Income Distribution", in Journal of Economics, 58, 1 (1993), pp. 53-75. Caballé, Jordi; Santos, Manuel S. "On Endogenous Growth with Physical and Human Capital”, in Journal of Political Economy, 101, 6 (December 1993), pp. 1042-67. Amendola, Giovanni; Dosi, Giovanni; Papagni, Erasmo "The Dynamics of International Competitiveness", in Weltwirtschaftliches Archiv, 129, 3 (1993), pp. 45271. Homburg, Stefan "Humankapital und endogenes Wachstum" in Zeitschrift für Wirtschafts - und Sozialwissenschaften, 115, 3 (1995), pp. 339-66. Grossman, Gene; 
ratio, which is incompatible with Marx and standard neoclassical thought, by adding factors to capital accumulation which are difficult to describe and even more difficult to explain. These factors are explained as the result of activities which can be pursued intentionally. There is no empirical proof to justify a rejection of the argument that these additional factors are simply the result of the old principle of capitalist growth, i.e., that large-scale production of identical items reduces the costs of technical discoveries and allows for their transformation into production processes based on better machinery. ${ }^{22}$ After a decade of research into the process of quasiinvestment in these new factors, new endogenous growth theory has admitted the importance of learning-by-doing and, finally, the demand-dependent character of technical progress. ${ }^{23}$ Innovation results from the discovery and generalized application of new production technologies. The experience gained at these new technical frontiers encourages new innovations, which can in turn be generalized. The diffusion process will be faster, the more the goods manufactured using these innovations are produced in large series. ${ }^{24}$ In this way more individuals will gain experience with new technologies. The widespread use of innovations can be considered the basis for further innovation. Among the two incentives for innovation - new goods and cheaper prices - the drive for new products, which is old as human history, has been a less powerful source of innovation than the drive for cheapening the manufacture of existing products, despite the artistic excellence of pre-capitalist societies such as Ancient Egypt, Ancient China, and Ancient India.

Learning-by-doing presupposes the time dependence on technical progress. At any point in time there is a multitude of technologies that contribute varyingly to costreduction, and therefore allow varying rises in the surplus value vis-à-vis the stock of capital. If the rate of capital accumulation is raised above the golden rule scenario ${ }^{25}$ - i.e., a constant capital productivity, with identical growth rates for net income and the net stock of fixed capital, and, hence, above the rate of time-dependent technical progress - , additional spending on investment has to be for projects

Helpman, Elhanan "Trade, Innovation and Growth", in American Economic Review, 80, 5 (1990), pp. 87-91. Lucas, Robert E. "On the Mechanics of Economic Development", in Journal of Monetary Economics, 22, 1 (March 1988), pp. 3-42.

${ }^{22}$ Elsenhans, Hartmut "Wirtschaftswachstum und institutionelle Entwicklung. Korreferat zum Beitrag von Rainer Klump" in Schubert, Renate (ed.): Neue Wachstums - und Außenhandelstheorie Implikationen für die Entwicklungstheorie und Politik (Berlin: Duncker \& Humblot, 1999) pp. 115-28.

${ }^{23}$ Romer, Paul M. "Why Indeed in America? Theory, History, and the Origins of Modern Economic Growth" in American Economic Review, 87, 2 (May 1996) pp. 202-6.

${ }^{24}$ Schmookler, Jacob Invention and Economic Growth (Cambridge, Mass.: Harvard University Press, $1966)$ pp. 187ff. Allen, Robert C. "Collective Invention" in Journal of Economic Behaviour and Organization, 4, 1 (1983) p. 17. Dosi, Giovanni; Pavitt, Keith; Soete, Luc, The Economics of Technical Change and International Trade (New York et al.: Wheatsheaf, 1990) pp. 90, $119 \mathrm{ff}$.

${ }^{25}$ Nuti, Domenico Mario “Capitalism, Socialism and Steady Growth" in Economic Journal, 80, 317 (March 1970) pp. 32-57. Phelps, Edmund S.: "Second Essay on the Golden Rule of Accumulation" in American Economic Review, 55, 4 (September 1965) pp. 793-814. 
which are characterized by lower-than-average technical innovation. There is too much "money" available in relation to the potential for technical progress. The lag in wage increases creates financial resources for which there is not yet sufficient technical progress.

Hence the decline of the profit rate is in fact the dire consequence of wages not expanding in line with productivity growth. Without acceleration of time-dependent technical progress, spending all available financial resources involves spending on less productive projects, which forcibly reduce the profit rate. The "overaccumulation" crisis has its roots in an insufficient expansion of labor incomes, which is temporarily compensated by the acceleration of accumulation; yet, it eventually leads to the decline of the profit rate and to unemployment. Overaccumulation is not radically different from underconsumptionism. ${ }^{26} \mathrm{~A}$ stoppage in the accumulation process due to underconsumption is nothing else than capitalists realizing in advance the futility of engaging in an acceleration of accumulation beyond the consumptive capacity of the society.

Capitalism depends on the availability of new products that can be produced without increasing capital intensity. This implies rising mass consumption from the demand side. ${ }^{27}$ Consumption is basically not able to limit profit, as Baran and Sweezy unintentionally demonstrated. ${ }^{28}$ Even in times of prosperity, workers cannot

\footnotetext{
${ }^{26}$ Even a neo-classical author has shown that if the economy enters a crisis, the return to a full employment situation may not be realized despite low wages. He refers to this as a secondary crisis, cf. Roepke, Wilhelm, Crises and Cycles (London et al.: William Hodge, 1936) p. 90: "There exists in fact a close connection between the fundamental ideas of the underconsumption theory and the overcapitalization doctrine [...], even though this connection may be difficult to acknowledge in the face of the unscientific formulation of the popular variety of 'the underconsumption theory"”.
}

${ }^{27}$ Strassmann, W. Paul "Economic Growth and Income Distribution”, in Quarterly Journal of Economics, 70, 3 (August 1956), pp. 425-40. Young, Allyn "Increasing Returns of and Economic Progress", in Economic Journal, 38, 152 (December 1928), pp. 528-42. Lafaiete Lopes, Francisco "Desigualdade e crescimento: um modelo de programação com aplicação ao Brasil", in Pesquisa e Planejamento Econômico, 2, 2 (December 1972), pp. 189-226. Murphy, Kevin M.; Shleifer, Andrei; Vishny, Robert "Income Distribution, Market Size and Industrialization", in Quarterly Journal of Economics, 104, 3 (August 1989), pp. 537-64 rediscovered this mechanism for endogenous growth theory. Cf. also Mommertz, Karl Heinz, Vom Bohren, Drehen und Fräsen. Zur Kulturgeschichte von Werkzeugmaschinen (Munich: Deutsches Museum, 1979), p. 121. Schlesinger, Georg "Die amerikanischen Werkzeugmaschinenausstellungen in New Haven und Boston”, in Werkstattgeschichte, 19, 1 (1925), p. 121. Freyberg, Thomas von, Industrielle Rationalisierung in der Weimarer Republik (Frankfurt am Main; New York: Campus, 1989), p. 59. Brasch, Hans "Der heutige Stand des amerikanischen Werkzeugmaschinenbaus für Massen - und Sonderleistungen”, in Maschinenbau, 3, 25 (October 1924), pp. 931-47. Hounshell, David A. From the American System to Mass Production 1800-1932. The Development of Manufacturing Technology in the United States (Baltimore, Md.; London: Johns Hopkins University Press, 1984), pp. 51ff. Barth, Ernst Entwicklungslinien der deutschen Maschinenbauindustrie von 1870-1914 (Berlin: Akademie-Verlag, 1973), p. 63. Young, Alwyn "Learning By Doing and the External Effects of International Trade", in Quarterly Journal of Economics, 106, 2 (May 1991), pp. 369-405.

28 They assume that profit is maintained by unproductive spending. Baran, Paul A.; Sweezy, Paul M. Monopoly Capital. An Essay on the American Economic and Social Order (New York: Monthly Review Press, 1967), pp. 62ff., esp. pp. 178ff. 
raise their consumption beyond the productive capacity for consumption goods. With fullemployment on the basis of existing capacity, capitalists can respond to further increases in demand only by increasing investment. Until new capacities can be put into operation, rising prices will help cover the costs of this additional investment. Labor and capital can be substituted in the neo-classical production function, but not at the macro-economic level, since labor cannot eat the output of investment goods industries, whereas productive capacity in consumption goods industries cannot increase without additional machinery.

There is an important implication for the rivalry between really existing socialism and capitalism in the twentieth century. In the planned economies, the share of investment in national income was able to increase far beyond the level of such shares in the capitalist West. But only during the crisis of the 1930s existing socialism was seriously considered capable of overtaking the capitalist West. ${ }^{29}$ When the bargaining power of labor rose after the defeat of fascism and the end of Soviet military expansion to the center of Europe, the West returned to full employment and high growth rates, whereas the high shares of investment in national incomes in the Soviet bloc were linked to high and rising capital-output ratios, interpreted by the people of these countries as quasi exploitation by an inefficient nomenclatura. ${ }^{30}$

This absence of a rise in the capital-output ratio under capitalist conditions and the absence of a decline in capital productivity are not the accidental result. On the contrary, they are the very expression of power relations between social classes in capitalism. Despite the manifold complaints about the power of money in capitalism, business has great difficulties engaging in the accumulation of wealth without developing productive forces - hence the scope for redistribution of income, and this not primarily via politically managed distributive measures but via the scarcity of labor whose marginal product is high. By developing productive forces and, consequently, the marginal product of labor, which constitutes the basis of its scarcity, the "ruling" class in capitalism empowers labor. The result of this is that the stock of fixed capital cannot grow more rapidly than labor productivity beyond an initial upstart period. ${ }^{31}$ Unintentionally and without the slightest insight into this process, the capitalist class is shielded from the decline of capital productivity because of the bargaining power of labor.

\footnotetext{
${ }^{29}$ Elsenhans, Hartmut, “The Rise and Fall of Really Existing Socialism”, in Journal of Social Studies, 87 (January/March 2000), pp. 1-16.

${ }^{30}$ Elsenhans, Hartmut State, Class and Development (New Delhi; London; Columbia, Mo.: Radiant; Sangam; South Asia Books, 1996), p. 144, fn. 89.

${ }^{31}$ The implications of this argument for so-called primitive accumulation cannot be discussed here. See Elsenhans, Hartmut "Rent and the Transition to Capitalism" in Asien-Afrika-Lateinamerika, 25, 6 (1997), pp. 651-86. The argument also has implications for the catching-up process, as it implies that catching up should normally occur by means of market forces (imitation, technology transfer) as well as by state measures (rent-financed imitation), Elsenhans, Hartmut "Underdevelopment, Nationalism, and the Free Market Economy" in Journal of Social Studies, 58 (October 1992) pp. 115-20.
} 


\section{GLOBALIZATION IS COMPATIBLE WITH FULL EMPLOYMENT IN DEVELOPED ECONOMIES}

Globalization will not lead to the disempowerment of labor if there is not an already existing mass of labor with low bargaining power, which is integrated into a larger labor market. The empirical proof of this is the relative stability of purchasing-power parity of exchange rates between major industrial countries ${ }^{32}$ as well as similar productivity lags in different branches between developed countries, ${ }^{33}$ but not between developed and underdeveloped countries. ${ }^{34}$

In the present globalization debate two arguments are frequently advanced. It is maintained that wages in a given country — usually one's own, e.g., Germany — are too high. This is believed to explain high levels of unemployment, which are the result of a lack of competitiveness at the international level. It is therefore advised to follow a policy of wage restraint, so that labor costs per unit of output decrease with the increase in productivity. The second argument is the demand for fair labor standards, namely, the improvement of labor standards in the underdeveloped world, with the aim of protecting the standards of the developed industrialized countries. ${ }^{35}$

In the system of flexible exchange rates, the observation that, for example,

\footnotetext{
32 Frenkel, Jakob A. "International Interdependence and the Constraints on Macroeconomic Policies" in Weltwirtschaftliches Archiv, 122, 2 (1986) p. 640. "Entwicklung und Bestimmungsfaktoren des Außenwerts der D-Mark" in Monatsberichte der Deutschen Bundesbank, 45, 11 (November 1993) pp. 51-6. Fortune, J. Neill "Expected Purchasing Power Parity" in Weltwirtschaftliches Archiv, 121, 1 (1985) pp. 97-104. Hakkio, Craig S. "A Re-examination of Purchasing Power Parity: A Multicountry Multiperiod Study" in Journal of International Economics, 17, 3 (1984) pp. 265-77. Abuaf, Niso; Jorion, Philippe "Purchasing Power Parity in the Long Run" in Journal of Finance, 45, 1 (March 1990) p. 172. Wasserfallen, Walter; Kyburz, Hans "The Behaviour of Flexible Exchange Rates in the Short Run. A Systematic Investigation" in Weltwirtschaftliches Archiv, 121, 4 (1985) p. 657. Siebert, Horst "Wirtschaftliche Zwänge für offene Volkswirtschaften" in Weltwirtschaftliches Archiv, 121, 4 (1985) pp. 609-27. Junge, Georg "Trends and Random Walks of Real Exchange Rates" in Weltwirtschaftliches
} Archiv, 121, 3 (1985) p. 435.

${ }^{33}$ Yukizawa, Kenzo "Changes in Japanese-United States Productivity Differentials and the Yen-Dollar Problem”, in Japanese Economic Studies, 1, 4 (Summer 1973) pp. 40ff. Rostas, László, Comparative Productivity in British and American Manufacturing (Cambridge: Cambridge University Press, 1948) p. 47. Pilat, Dirk; Rao, P. S. Prasada "Multilateral Comparisons of Output, Productivity, and Purchasing Parities in Manufacturing", in Review of Income and Wealth, 42, 2 (June 1996), pp. 113-20. Ark, Bart van, International Comparisons of Output and Productivity. Manufacturing Productivity Performance of Ten Countries from 1950-1990 (Groningen: Groningen Growth and Development Centre, 1993) pp. $101 \mathrm{ff}$. Flux, A.W. "Industrial Productivity in Great Britain and the United States", in Quarterly Journal of Economics, 47, 1 (November 1933), p. 33. Levine, Aaron Lawrence, Industrial Retardation in Britain 1880-1914 (Letchworth: Weidenfeld \& Nicolson, 1967), p. 20. Maddison, Angus, Economic Growth in the West. A Comparative Experience in Europe and North America (New York; London: Twentieth Century Fund; Allen \& Unwin, 1964), p. 37.

34 Pilat, Dirk "Comparative Productivity of Korean Manufacturing, 1967-1987" in Journal of Development Economics, 46, 1 (February 1995) p. 140.

${ }^{35}$ Langille, Brian A. "Eight Ways to Think About International Labour Standards" in Journal of World Trade, 31, 4 (August 1997) pp. 27-54. Waer, Paul "Social Clauses in International Trade - The Debate 
Germany's labor costs are too high does not lend support to any explanation other than the one that simply says that Germany's international competitiveness remains untouched as long as Germany does not have a balance-of-trade deficit (including services). German labor is internationally expensive via the exchange rate because it is productive. If Germany's labor were too expensive, German products would not sell on the world market, and, as a consequence, the German currency would depreciate. Currency fluctuations have been far more important in the case of Germany than changes in nominal wages.

If Germany resorts to further cuts in labor costs, its exports will further increase along with its export surplus. As long as capital flows supply purchasing power to the rest of the world, Germany can continue to ease its problem of unemployment by exporting surpluses, to the detriment of potential employment in its own consumer economy. Without such capital flows, German currency will become scarce and appreciate. ${ }^{36}$ In early 1995 , German managers appeared in a lavishly sponsored TV campaign where they appealed for wage restraints. The campaign was stopped when the DM rose against a massively devaluating US\$ to $1 \mathrm{DM}$ per 0.75 , to compare to the about $1 \mathrm{DM}$ per 0.66 US $\$$ in ordinary times or $1 \mathrm{DM}$ to less than 0.50 US\$ actually.

Full employment in all participating economies also leads to equalization of productivity lags in various branches. Some economies may enjoy comparative advantage in a particular branch and specialize on this branch because of the good earnings for the factors of production engaged here. They compete for labor on the local labor market, and force businesses that are oriented towards the internal market to either charge higher prices or to modernize their production processes, if labor becomes scarce because of the export drive. Businesses which cannot maintain their competitive position by either charging higher prices or by improving productivity will not survive. The equalization of productivity differences across branches of production does not stem from parallelisms in technical development - which, of course, may exist as well - but from the simultaneous operation of competition and scarcity of labor.

If the globalization process only links economies tending to full employment, it takes the form of a convoy process. ${ }^{37}$ An innovation in tradables in a technically leading economy adds to its comparative advantage and opens up new export potential. Without capital flows to the rest of the world, the currency of the innovating economy appreciates. The non-innovative economy gains new possibilities

in the European Union" in Journal of World Trade, 30, 4 (August 1996) pp. 25-42. Feld, Lars P. "Sozialstandards und Welthandelsordnung" in Außenwirtschaft, 51, 1 (1996) pp. 51-73.

${ }^{36}$ Deutsches Institut für Wirtschaftsforschung “Gefährdet die Lohnkostenentwicklung die Wettbewerbsfähigkeit der Bundesrepublik Deutschland" in DIW-Wochenbericht, 59, 11 (12 March 1992) p. 125.

${ }^{37}$ Elsenhans, Hartmut “Globalization or Dutch Disease: Its Political and Social Consequences" in Singer, Hans Wolfgang; Hatti, Neelambar; Tandon, Rameshwar (eds.), New World Order Series, Volume 16 (PartI) Technological Diffusion in Third World (New Delhi: B.R. Publishing Corporation, 1999) pp. 438-41. 
for exports and import-substitution at low levels of devaluation if its productivity lag is low in non-innovative branches where it previously did not enjoy comparative advantage. As the costs of production in the innovative economy rise, the non-innovative economy may even benefit from improving terms of trade through specialization on backward products. The less the productivity lags of the non-innovative economy in hitherto internationally uncompetitive and non-innovative branches, the earlier this economy benefits from new export opportunities through the inevitable devaluation of its currency.

This possibility of specialization on non-innovative products has two implications. The non-innovative economy does not experience unemployment due to innovation in the innovative economy. It suffers only limited set-backs in its overall terms of trade, but cannot compensate its lag in leading technologies by devaluation of its currency. Its exports grow on the basis of old products even at low rates of devaluation.

It is still possible for the backward economy to overtake the advanced one on the basis of low lags in productivity in new products, at least relative to the high productivity lags in old products. This was the case in Britain's overtaking France in low quality but cheap industrial products in the late eighteenth century, ${ }^{38}$ and

Germany's overtaking Britain in chemicals and electrical products at the end of the nineteenth century. ${ }^{39}$ But the number of cases is limited, because at that time not only the international monetary regime but also the relatively high productivity in backward branches of the lagging-behind economies limited devaluation.

In line with the observation of path dependency formulated in the theory of endogenous growth, a leading economy with considerable experience in old products may achieve higher productivity in new products than catching-up economies. But because technical progress stems from learning-by-doing - hence from production where the leader is more active than the follower - , it is highly improbable that the leader enjoys productivity advances in new products to the extent of those in old products.

\section{DEVALUATION-BASED EXPORT DRIVES CHARACTERIZE THE STRATEGY OF SUCCESSFUL DEVELOPING COUNTRIES}

In contrast to the early twentieth century, the present globalization drive is characterized by the integration of marginality-ridden underdeveloped countries

\footnotetext{
${ }^{38}$ Crafts, Nicholas F.R. "British Industrialization in an International Context" in Journal of Interdisciplinary History, 19, 3 (Winter 1989) pp. 415-28.

${ }^{39}$ Kindleberger, Charles P. “Germany's Overtaking of England 1806-1914 (2)”, in Weltwirtschaftliches Archiv, 111, 3 (1975), pp. 477-504. Aukrust, Odd "Factors of Economic Development: A Review of Recent Research", in Weltwirtschaftliches Archiv, 93, 2 (1964), pp. 23-43. Fremdling, Rainer "Productivity Comparisons between Great Britain and Germany, 1855-1913", in Scandinavian Economic History Review, 39, 1 (1991), pp. 28-42.
} 
into the world economy on the basis of their capacity to supply cheap industrial products. This export drive, however, is not powerful enough to raise employment to levels where labor becomes scarce in the whole of the "overpopulated" area of the so-called Third World.

A benign and a malign case can be distinguished. In the benign case, the neoclassical mechanism can operate due to the scarcity of labor, which enables real wages to increase, as has been the case in South Korea or Taiwan. ${ }^{40}$ In the malign case, the export drive is too weak to dynamize the rest of the economy. With low levels of employment, devaluation continues to be an important instrument for capturing shares of the world market, which is rendered possible by the existence of considerable agricultural surpluses, improving terms of trade between simple industrial products and food on the world markets, and the possibilities of technology transfers through foreign direct investment and government intervention. ${ }^{41}$ Devaluation-based export drives constitute the essential aspect of the globalization process with respect to West-South relations..$^{42}$ Because the process is devaluation-driven, the attempts to check the new competitiveness of the underdeveloped countries by wage restraint cannot succeed. Devaluation is possible if wage goods are locally produced, since, in this case, the additional income paid out to export workers is primarily transformed into demand for the locally produced surplus of food and wage goods, mostly from the informal sector. ${ }^{43}$

It is not the poor countries of sub-Saharan Africa, but the agriculturally successful rice-growing countries of East and Southeast Asia which have been most successful in launching devaluation-driven export drives, as they have been able to supply the wage goods for their export workers from locally existing productive capacities. Economies are more successful, the less import-dependent they are. Fe-

\footnotetext{
${ }^{40}$ Fields, Gary S. "Changing Labor Market Conditions and Economic Development in Hong Kong, the Republic of Korea, Singapore and Taiwan China”, in World Bank Economic Review, 8, 3 (September 1994), pp. 395-414.

${ }^{41}$ Elsenhans, Hartmut, "The Relevance of the Principles of Keynesian Economics for the Transition to Capitalism in Today's Underdeveloped World", in Davidson, Paul; Kregel, Jan E. (eds.) Improving the Global Economy. Keynesianism and the Growth in Output and Employment (Cheltenham: Edward Elgar, 1997), pp. 291-4.

${ }^{42}$ Tzannatos, P. Zafiris, International Competitiveness in East Asian Manufacturing: Unit Labour Cost Analysis for Selected Countries (Washington: World Bank, 1997), pp. 2-3. Guillaumont-Jeanneney, Sylviane; Hua, Ping "Politique du change et développement des exportations manufacturées en Chine", in Revue économique, 47, 3 (May 1996), pp. 851-60. Lafay, Gérard "Les origines internationales du chômage européen", in Revue d'économie politique, 106, 6 (November/December 1996), pp. 948, 963. Narrassiguin, Philippe "Croissance tirée par les exportations et politique de change: Le cas de l'île Maurice”, in Revue d'économie politique, 105, 2 (March 1995), p. 325. Most recently: Mundorf, Hans "Amtliche Wechselkurse dienen oft der Verfälschung der Wirklichkeit", in Handelsblatt (28/29 August 1998), p. 2.

${ }^{43}$ Bhagwati, Jagdish N. "Why Are Services Cheaper in Poor Countries", in Economic Journal, 94, 374 (June 1984), pp. 279-86.
} 
lix ${ }^{44}$ has shown that East and Southeast Asia are characterized by a low import propensity of their higher income strata, in contrast to Latin America.

Low international labor costs therefore do not mean low real wages. The domestic purchasing power of household incomes in the case of East Asia and Eastern Europe is a multiple of the purchasing power these incomes would yield if converted into dollars and used in a typical industrialized country of the West. ${ }^{45}$

The higher real purchasing power of an income on the local market in relation to its purchasing power on the world market implies a relatively high productivity in non-tradable sectors, including food production given the highly regulated world market in basic foods. Devaluation-driven export-led industrialization of the East and Southeast Asian type was made possible through early agrarian reforms which allowed mobilizing marginal labor, as predicted in theories on agrarian reform such as those based on the labor-surplus argument, ${ }^{46}$ or on the Latin American "macrofundio-microfundio" theoretical construct. ${ }^{47}$

Labor has experienced productivity increases via real wage increases. The Washington institutions have referred to this as shared development. ${ }^{48}$ Export-led industrialization in East and Southeast Asia has also been rent-based. Amsden${ }^{49}$ coined the phrase which was followed as a principle: "get your prices wrong." Akyüz and Gore ${ }^{50}$ spoke of systematically created rents, and even free marketeers did not claim that the highly performing economies of East and Southeast Asia were characterized by free markets, but spoke of market-friendly or market-enhancing

\footnotetext{
${ }^{44}$ Felix, David, Industrial Development in East Asia: What are the Lessons for Latin America. Discussion Paper 84 (Geneva: UNCTAD, 1994), p. 14.

${ }^{45}$ Cf. Mundorf 1998, art. cit., fn. 45, p. 2, who quotes an OECD study. Mussler, Werner "Die Senkung der Arbeitskosten erfordert einen langen Atem: Deutschland dürfte auf absehbare Zeit Spitzenreiter bleiben — Lohnsteigerungen dieses Jahres wirken kontraproduktiv", in Handelsblatt (14 July 1999), p. 2. Yotopoulos, Pan A.; Lin, Jenu-Yih "Purchasing Power Parities for Taiwan: The Basic Data for 1985 and International Comparisons”, in Journal of Economic Development, 18, 1 (June 1993), p. 11. Chen, Haichun; Gordon, M.J.; Yan, Zhiming "The Real Income and Consumption of an Urban Chinese Family”, in Journal of Development Studies, 31, 1 (October 1994).
}

${ }^{46}$ Georgescu-Roegen, Nicholas "Economic Theory and Agrarian Economics", in Oxford Economic Papers, 12, 1 (February 1960), pp. 32-40. Dandekar, V.M. "Economic Theory and Agrarian Reform", in Oxford Economic Papers, 14, 1 (February 1962), pp. 69-80. Sen, Amartya Kumar "Peasants and Dualism with or without Surplus Labour", in Journal of Political Economy, 74, 5 (October 1966), pp. 427-50.

${ }^{47}$ Feder, Ernest "The Latifundia Puzzle of Professor Schultz; Comment”, in Journal of Farm Economics, 49, 2 (May 1967), pp. 507-11. Sternberg, Marvin J. "Agrarian Reform and Employment, with Special Reference to Latin America”, in International Labour Review, 95, 1/2 (January/February 1967), pp. $1-26$.

${ }^{48}$ Page, John et al. The East Asian Miracle. Economic Growth and Public Policy (Washington: World Bank, 1993), pp. $157 \mathrm{ff}$.

${ }^{49}$ Amsden, Alice H. Asia's Next Giant (New York; Oxford: Oxford University Press, 1989), p. 139.

${ }^{50}$ Akyüz, Ylmaz; Gore Charles, The Investment-Profits Nexus in East Asian Industrialization. Discussion Paper 91 (Geneva: UNCTAD, 1994). 
approaches ${ }^{51}$ where the market was used to discipline private enterprise without being allowed to guide major development decisions, especially concerning the launching of new activities.

The empirical evidence of states mobilizing rents which are subsequently allocated to politically determined strategies of economic growth and diversification within the framework of a controlled opening to the world market is not a coincidence, but a necessary consequence of the structure of capitalist growth. Any type of production has two results: a product which can be sold and a transformation of labor and infrastructures which improves productivity in the future. Technically backward economies in particular will often have comparative advantage in branches with low productivity-enhancing effects.

If the internal market is not sufficiently large - due to population levels, the extent of economies of scale, which are much higher today than in the period when European continental economies (and also the USA) were catching up with Britain, and high levels of poverty - the nineteenth-century solution (applied in Latin American import-substituting industrialization since the 1940s) will not work, so that export orientation is inevitable.

But also the implied solution of cheapening exports is based on rents. Levels of devaluation where purchasing-power parity is not respected are possible because of productivity levels in the production of non-tradables, which are relatively higher, compared to the world economy, than the productivity levels in the respective export sectors. This mechanism is especially important in the case of local food production, where non-tradability is induced artificially by keeping local farmers from exporting, for example, through monopolies on state-trading organizations or export taxes.

Export-sector employment is therefore a function of devaluation and of the capacity to subsidize the export sector, and thus, ultimately, a function of the agricultural surplus. The locally produced rent is channeled in its physical form to additional workers in the export sector who are hired in the case of devaluation. Part of the value of this rent goes to consumers in the industrialized world who enjoy rising incomes due to improved terms of trade between the branches which remain in their countries and those branches which migrate to the low-labor-cost economies. The implied exploitation of the catching-up economy can be limited by complementing devaluation with state-guided rent allocation to specific sectors of production or to factor-supply improvement.

The strategy of "remonter les filières" 52 — which was advocated quite strong-

\footnotetext{
51 Aoki, Masahiko; Murdock, Kevin; Okuno-Fujiwara, Masahiro, Beyond the East Asian Miracle. Introducing the Market Enhancing View. CEPR Publication 442 (Stanford, Calif.: CEPR, 1995).

${ }^{52}$ For example, Aoudia, Jacques Ould "Les enjeux économiques de la nouvelle politique méditérranéenne de l'Europe" in Maghreb-Machrek/Monde Arabe, 153 (July/September 1996) p. 35. Sid Ahmed, Abdelkader, Development and Resource-Based Industry. The Case of the Petroleum Economies. A Brief Survey of Recent Studies (Vienna: OPEC Fund for International Development, 1990) p. 61.
} 
ly in the French discussion, especially for raw-material exporters (oil countries), where rents were used for developing forward and backward linkages of the oil industry - is certainly also possible with respect to industrial exports. In the 1970s, South Korea faced declining prices for its textile exports with low price elasticity of demand. The quantities exported could rise only with a fall in price where the total earnings from these exports decreased. A government ban on the import of textile machinery forced local textile producers to turn to the local (small and medium) metal working sector for their machinery, which was initially quite expensive with respect to performance. The additional costs were passed on to the customer (and limited the possibilities of price cutting). In the end, Korean textile machinery producers benefited from learning-by-doing on the basis of close advice from their local customers, who knew perfectly well which machinery they needed. ${ }^{53}$ Korean textile-machinery exporters rapidly acquired technical efficiency and became competitive on the world market. A similar strategy was followed by Singapore, where in the 1970s enterprises with low per capita wage bills (because of the employment of unskilled labor) had to pay special taxes which were used for financing efforts to upgrade the skills of labor (with less success than the South Korean strategy)..$^{54}$

In the case of specialization on branches with low elasticity and low productivityenhancing effects - not only in the raw-material sector, but also industrial branches - rent appropriation is possible by means of devaluation because there is the possibility of combining low exchange rates with taxation of those products where competitiveness would already be achieved at higher exchange rates. ${ }^{55}$ Not yet competitive labor is subsidized from taxes on exports, which many countries have also levied on manufactured products (e.g., auctioning of textile import quotas ${ }^{56}$ ).

\footnotetext{
${ }^{53}$ Mytelka, Lynn Krieger “The Transfer of Technology: Myth or Reality?”, in Cosgrove, Carol; Jamar, J. (eds.) The European Community's Development Policy: The Strategies Ahead (Brugge: De Tempel, 1986), p. 258. The rational character of their option is argued by Jung, Woo S.; Lee, Gyn "The Effectiveness of Export Promotion Policies: The Case of Korea", in Weltwirtschaftliches Archiv, 122, 2 (1986), pp. 34058. Elsenhans, Hartmut "Handlungsspielräume für reformistische Entwicklungsstrategien" in Evers, HansDieter; Senghaas, Dieter; Wienholtz, Huberta (eds.) Auf dem Weg zu einer Neuen Weltwirtschaftsordnung? Bedingungen und Grenzen für eine eigenständige Entwicklung (Baden-Baden: Nomos, 1983), p. 145.

${ }^{54}$ Holtgrave, Wilfried, Industrialisierung in Singapur. Chancen und Risiken industrieorientierter Spezialisierung (Frankfurt am Main; New York: Campus, 1987), pp. 59-81.

${ }^{55}$ Kaldor, Nicholas “Dual Exchange Rates and Economic Development”, in Economic Bulletin for Latin America, 9, 2 (November 1964), p. 220. World Bank, World Development Report 1987 (New York, et al.: Oxford University Press, 1987), p. 98. Balassa, Bela "Tariffs and Trade Policy in the Andean Common Market", in Journal of Common Market Studies, 12, 1 (1974), p. 178. Katseli, Louka T. "Devaluation: A Critical Appraisal of the IMF's Policy Prescriptions", in American Economic Review, 73, 2 (May 1983), p. 362.

${ }^{56}$ Morkre, Morris E. “Rent-Seeking and Hongkong's Textile Quota System”, in Developing Economies, 17, 1 (March 1979), pp. 110-8. Takacs, Wendy E. “Economic Aspects of Quota Licensing Auctions”, in Journal of World Trade, 22, 5 (October 1988), p. 41. World Bank, op. cit, fn. 82; p. 148. Khanna, Sushil
} 
The more exports are import-dependent - e.g., because of the use of imported technology - the less the products can be cheapened by devaluation, as devaluation has an impact only on the local factors of production.

There are limits to devaluation if products which have to be exported are manufactured with high costs of physical capital, so-called capital-intensive products. At the same time, low skill levels in underdeveloped countries create comparative advantage in these products, much more than in high-skill labor-intensive products,${ }^{57}$ as already observed in the Leontief paradox. ${ }^{58}$

In order to overcome obstacles to market penetration, the underdeveloped economy has to diversify into the local production of technology and inputs in order to achieve further price cuts, despite the high local prices of these inputs. There is a fundamental difference between the cost of imported equipment and locally produced equipment. Locally produced equipment can be produced regardless of the price of local labor and other local factors of production without endangering the capacity to devalue, even if imported equipment is cheaper at the chosen exchange rate. ${ }^{59}$ Diversification into investment-goods production makes sense even if the cost of this equipment is higher than imported equipment, as long as the priceelasticities of current exports limit the earning capacity of the respective economy for foreign exchange at the prevailing exchange rate.

With respect to rent channeling with the aim of success in exports, a benign and a malign case can be distinguished. The malign case consists in not overcoming

"Market Sharing Under Multifiber Arrangement: Consequences of Non-Tariff-Barriers in the Textile Trades”, in Journal of World Trade, 24, 1 (February 1990), p. 93.

${ }^{57}$ Boatler, Robert W. "Trade Theory Predictions and the Growth of Mexico's Manufactured Exports”, in Economic Development and Cultural Change, 23, 4 (July 1975), p. 406. Boatler, Robert W. "Comparative Advantage; A Division among Developing Countries", in Interamerican Economic Affairs, 32, 2 (Autumn 1978), pp. 59-66. Clague, Christopher K. "An International Comparison of Industrial Efficiency: Peru and the United States”, in Review of Economics and Statistics, 49, 4 (November 1967), pp. 487-93. Clague, Christopher K. "Capital-Labour Substitution in Manufacturing in Underdeveloped Countries" in Econometrica, 37, 3 (July 1969), pp. 528-37. Clague, Christopher "Relative Efficiency, SelfContainment and Comparative Costs of Less Developed Countries", in Economic Development and Cultural Change, 39, 2 (April 1991), pp. 506-30. Bruton, Henry J. "Import Substitution and Productivity Growth”, in Journal of Development Studies, 4, 3 (April 1968), pp. 306-26. Bitar, Sergio; Moyano, Eduardo "Redistribución del consumo y transición al socialismo", in Garretón, Manuel Antonio (ed.) Economia politica en la Unidad Popular. Materiales de los Cuadernos de la Realidad Nacional (19701973) (Barcelona: Editorial Fontanella, 1975), p. 237. Hardin, Einar; Strassmann, W. Paul "La productividad industrial y la intensidad de capital de México y los Estados Unidos", in Trimestre Económico, 35, 137 (1968), pp. 51-61. Diaz-Alejandro, Carlos F. "Industrialization and Labour Productivity Differentials”, in Review of Economics and Statistics, 47, 2 (May 1965), pp. 207-13.

${ }^{58}$ Leontief, Wassily "Domestic Production and Foreign Trade: The American Capital Position ReExamined", in Economia Internazionale, 7, 1 (1954), pp. 9-38. Leontief, Wassily "Factor Proportions and the Structure of American Trade: Further Theoretical and Empirical Analysis" in Review of Economics and Statistics, 38, 4 (November 1956), pp. 386-407.

${ }^{59}$ Elsenhans, Hartmut "Rent and Technology Distortion: The Two Cul-de-Sac of State Correction and Market Orientation in IAC and IBC", in Journal of the Third World Spectrum, 6, 1 (Autumn 1999), pp. $41 \mathrm{ff}$. 
low marginal productivity in wage goods production. The consequence is persistent marginality. Wages will not follow productivity increases in the export sector because of continuing unemployment.

In the benign case, technical progress will raise marginal productivity either because of an ever growing export sector or because of the export sector's dynamic role in modernizing the rest of the economy. The internal market will also develop, and, ultimately, even imports will increase. Even if real wages were repressed, the tendency to full employment on the basis of the expansion of technical efficiency from export sectors to the whole of the economy would lead to exports in a large variety of branches of production, having as outcome considerable export surpluses. In the case of full employment, the consequences would be either "imported" inflation, as experienced by Germany at the end of the 1960s, or currency appreciation, as experienced by Japan in the 1990s.

The benign case is characterized by the spread of productivity growth to the entire economy, the malign case by sectorally limited productivity growth.

Growth therefore depends either on rent-financed subsidies to technology improvement in lines of production chosen by the state or an institution of the nonmarket economy, or on an equally state-dependent strategy which tries to imitate the growth mechanism of self-centered capitalism, i.e., the growth of the internal market, technical improvement and capital accumulation depending on rising mass incomes which triggers off innovation through small and medium-scale enterprises. Export-led growth has been most successful where a combination of these two strategies was used, with export drives being linked and supporting an improvement of income distribution. $\mathrm{Yi}^{60}$ has shown that small-scale industry in Taiwan was launched most effectively in local investment-goods production, and that Korea was willing to accept much larger inequalities of income distribution than Taiwan, despite comparable levels at the start.

Export-oriented industrialization does not escape the contradictions of rent. The East Asian literature - in contrast to the North American - has always insisted on the rent-dependent inefficiencies of the political systems of these countries. ${ }^{61}$ The East Asian countries have been quite successful in applying industrial policies, not because their bureaucracies are more efficient than the ones in industrialized countries, but because catching-up economies do not have to make sector choices, but can modify their industrial structures simply by imitating the examples of more advanced countries. ${ }^{62}$

\footnotetext{
${ }^{60}$ Yi, Guk-Yueng, Staat und Kapitalakkumulation in ostasiatischen Ländern: Ein Vergleich zwischen Korea und Taiwan (Saarbrücken: Breitenbach, 1988), pp. 91-102. Fujita, Natsuki; James, William E. "Export Oriented Growth of Output and Employment in Taiwan and Korea, 1973/74-1983/84", in Weltwirtschaftliches Archiv, 126, 4 (1990), pp. 737-53.

${ }^{61}$ Rhee, Jong-Chan, The State and the Industry in South Korea. The Limits of the Authoritarian State (London: Routledge, 1994), pp. 232-8.

${ }^{62}$ Leff, Nathaniel H. "Optimal Investment Choice for Developing Countries. Rational Theory and Rational Decision-Making”, in Journal of Development Economics, 18, 4 (August 1985), pp. 347ff.
} 
Democratization only took root in these countries when labor became scarce, and hence powerful. Due to the expanding internal market, new business groups arose, whose memberships were too large to be able to benefit from privileged links to the state. ${ }^{63}$ The development of the rule of law in Europe serves as a historical model for this process. The traditional pattern of transition from pre-capitalist to capitalist structures can be realized if labor becomes scarce. ${ }^{64}$ It is not the state which is essential for the catching-up process, as Gerschenkron suggests, ${ }^{65}$ but the state's incapacity to block the capitalist process if labor has become scarce.

The models of export-oriented industrialization presented here imply the existence of various underconsumption threats. Devaluation of the catching-up economies means improving terms of trade for the leading economies. Productivityoriented wage development requires that wages rise not only on the basis of increasing average rates of productivity but also due to improving terms of trade, so that the process of delocalization of production tends to accelerate.

Furthermore, as the international prices of products whose production has been delocalized from the leading industrialized countries to the catching-up economies may fall because of decreasing costs, the value of exports of the catching-up economy may be quite low. In this case, a country with a balance of trade deficit could present an underconsumption threat to the world economy.

Such immizering ${ }^{66}$ growth has long been observed in the discussion about terms of trade for raw material exporters in the underdeveloped South. Despite growing productivity, their terms of trade and their incomes may decrease. ${ }^{67}$ The possibility of decreasing terms of trade also in the case of specialization on manufactured products was proven by the Asian crisis, where the local currency prices of exported manufactures did not increase despite massive devaluation. Devaluation was the consequence of decreasing dollar prices of exported manufactures.

Paqué, art. cit., fn. 24, p. 250. Hofmann, Bert; Koop, Michael J. "Die 'Neue Wachstumstheorie' und ihre Bedeutung für die Wirtschaftspolitik", in Weltwirtschaft, 2 (1991), pp. 93ff. Elsenhans, Hartmut "La transition à l'économie de marché à partir d'économies sous-développées" in Naqd - Revue d'études et de critique sociale, 17, 3 (June/November 1992), p. 24.

${ }^{63}$ Kim, Sun-Hyuk "Civil Society in South Korea: From Grand Democracy Movements to Petty Interest Groups", in Journal of Northeast Asian Studies, 15, 2 (Summer 1996), pp. 81-97. Lee, Su-Hoon "Transitional Politics of Korea, 1987-1992: Activation of Civil Society", in Pacific Affairs, 66, 3 (Autumn 1993), p. 353.

${ }^{64}$ Elsenhans, Hartmut "Autonomy of Civil Society, Empowerment of Labour, and the Transition to Capitalism”, in Jain, Randhir B.; Khator, Renu (eds.): Bureaucracy — Citizen Interface: Conflict and Consensus (New Delhi: B.R. Publishing Corporation 1999), pp. 23-8.

${ }^{65}$ Gerschenkron, Alexander, Economic Backwardness in Historical Perspective (Cambridge, Mass.: The Belknap Press of Harvard University Press, 1962).

${ }^{66}$ Bhagwati, Jagdish N. "Immizering Growth: A Geometrical Note”, in Review of Economic Studies, 25, 68 (1958), pp. 201-4.

${ }^{67}$ Prebisch, Raúl "The Economic Development of Latin America and its Principal Problems", in Economic Bulletin for Latin America, 7, 1 (February 1962), pp. 1-2. 


\section{GLOBALIZATION ALSO DISEMPOWERS LABOR IN ADVANCED CAPITALIST COUNTRIES, BUT ONLY IN A SPECIFIC MANNER}

The sectoral competitiveness of the underdeveloped economies of the South destroys the economic and social cohesion of labor in the West and blocks the process of redistribution of incomes. Capitalist redistribution, however, constitutes the economic basis of the working classes. The possibility of redistribution is the condition for the existence of the working class as a political factor - a condition which is a constituent part of capitalist economies and their autonomous civil societies. $^{68}$

Capitalism involves the redistribution of financial resources among labor. As labor productivity increases differ from branch to branch, labor from branches with below-average productivity increases is hired by branches with above-average productivity increases by means of higher wages. The branches with below-average productivity increases reduce their output, can sell this reduced output at higher prices, and indeed have to do so in order to defend their earnings so that they themselves can pay higher wages to the labor they want to retain.

Specific activities cannot be associated with particular levels of productivity, nor can an interbranch comparison of the productivity of various activities establish a link between levels of productivity and the development in physical productivity. Engel ${ }^{69}$ was one of the first to show that utility is no measure. The teacher who helps create the productive capacity of a pupil is not able to capture the gain in productivity of this pupil. The physical productivity of a barber in Europe is not higher than that of a barber in India, but their incomes are not equal. The physical productivity of barbers has not increased in the last five centuries, but the incomes of barbers in the industrially advanced countries have followed average productivity increases.

Capitalism is based on redistribution. Unlike a feudal lord, the capitalist realizes profits on the basis of social relations, especially demand conditions based on net investment spending. Labor whose productivity does not increase benefits from the productivity increase of other labor - despite its own technical efficiency remaining the same - via changes in relative prices in favor of its own products. This mechanism requires tendential full employment. Without tendential full employment, labor in different branches will engage in a struggle over the relative importance of their respective specialization, that is, over the utility of labor. The now centuryold discussion in Marxist theory about the reduction of concrete labor into

\footnotetext{
${ }^{68}$ Kim, Hong Joo "Kanalisierung von Renten und Transitionsproblematik — am Beispiel der Republik Korea" in Zinecker, Heidrun (ed.) Unvollendete Demokratisierung in Nichtmarktökonomien. Die Blackbox zwischen Staat und Wirtschaft in den Transitionsländern des Südens und Ostens (Amsterdam: G+B Verlag Fakultas, 1998), pp. 57-70.

${ }^{69}$ Engel, Ernst, Die Lebenskosten belgischer Arbeiter-Familien früher und jetzt (Dresden: Heinrich, 1895), p. 3.
} 
abstract labor as a unit of value only shows that this issue cannot be resolved. ${ }^{70}$ What can be resolved, but only through the choice of professions and specialization, is equality with respect to the pains of labor - from the efforts of learning to the exertion of muscle power.

The mechanism of equalization of pay for equally "difficult" labor despite differences in productivity growth is the basis of the bargaining power of labor, as it allows organized labor to become a political factor despite its lack of property. This basis is threatened by the new competitiveness of labor from the low-labor-cost countries. Labor whose productivity growth is less than average is no longer able to impose wage increases in line with the average productivity increase of the technically advanced economies, because its unit costs rise on the world market, making labor with stagnant unit costs more competitive, because the rise in productivity in the technically most dynamic branches of the technically advanced countries is associated with exchange rate increases or other forms of terms-of-trade increases.

Because of high productivity in technically leading branches, the exchange rate of a technically leading country becomes so high that its labor in less productive branches is too expensive vis-à-vis labor in production sites whose international labor costs are not determined by such high technology branches.

Labor in the less dynamic branches of the technically advanced countries may lose competitiveness against the labor of low-cost production sites despite a very high productivity in relation to these competitors. At the same levels of income, labor in the West may not enjoy the - in international comparison - cheap nontradables which its counterpart at the low-labor-cost production sites consume. It is not impossible that real wages in the West for this type of labor may become even lower than in the South, despite this labor being too expensive to be competitive. With the emergence of newly competitive production sites in the South through devaluation, labor in the West cannot assure that it maintains its competitiveness on the basis of wage restraint, although its disempowerment leads to wage compression, possibly together with currency appreciation.

The underconsumption threat presented by the South is therefore complemented by additional underconsumption tendencies in the West. The decreasing competitiveness of Western labor in branches with below-average productivity growth cannot be solved through market mechanisms if the still highly competitive high-productivity-growth sector in the West does not grow rapidly. The normal case of adjusting differences in average productivity growth and of the declining competitiveness of low-productivity-growth industries is characterized by structural change in the product mix of the leading country. The growth of markets for the sector with high productivity growth depends mostly on the industrially advanced

\footnotetext{
${ }^{70}$ Pietsch, Anne-Jutta, Das Reduktionsproblem und die Kategorien produktive und unproduktive Arbeit. Ein Beitrag zur politischen Ökonomie des Ausbildungssektors (Frankfurt am Main; New York: Campus, 1979). Morishima, Michio, Marx's Economics. A Dual Theory of Value and Growth (Cambridge: Cambridge University Press, 1973), p. 4.
} 
countries (hightechnology consumption goods) and their capacity to import from the catching-up economies, as the latter will not buy additional high-technology equipment without the perspective of expanding outlets in the industrially more advanced countries.

Wage restraint induces a vicious circle by limiting the growth of those sectors which could absorb labor from declining sectors. It is therefore not surprising that, statistically, the loss of jobs in the technically advanced countries does not stem from the employment balance of exports and imports between the West and the South but from productivity growing more rapidly than production in the West. The divergence between productivity growth and production is simply an indication of an underconsumption situation. ${ }^{71}$

Labor which is not successfully absorbed by a shift from sunset to sunrise branches will address itself to the state. State-led employment programs invariably involve increased state intervention on the basis of additional financial resources being extracted from the highly competitive sectors, i.e., rents.

Protectionism is but one form. Although rejected by the international financial institutions it shares a common characteristic with the market-friendly approach so staunchly advocated by the Washington preachers of worldwide liberalism, as it discriminates only against foreign enterprises, but puts all local (national or regional) enterprises on an equal footing while maintaining (some) competition. It is the least harmful form of rent-channelling for the industrially advanced country as it limits rent-seeking in comparison to other strategies as state-financed employment in activities which do not earn market prices for their products. Protectionism adds, however, to the underconsumption threats in the South as the transformation of the internal surplus of wage goods into employment via the market becomes more difficult. It limits the foreign exchange earnings of catching-up economies as the rates of devaluation for becoming competitive increase.

The development of socially protected activities in the industrialized countries, which the market cannot bear because consumers will not buy them at their costs of production, creates a state-dependent sector. Those who depend on this employment become a political force which will not be willing to accept future cut-backs in state resources used to support of this sector. Even under less universalistic communication and participation, Malthus ${ }^{72}$ did not succeed in demolishing the English Poor Laws ${ }^{73}$ before an alternative system of welfare was established. The proposals

\footnotetext{
${ }^{71}$ Thompson, Grahame “The American Industrial Policy Debate: Lessons for the U.K.” in Economy and Society, 16, 1 (February 1987) p. 13. Michie, Jonathan; Pitelis, Christos "Demand and Supply-Side Approaches to Economic Policy" in Work, Unemployment and Need: Theory, Evidence, Policies (Antwerpen: European Association for Evolutionary Political Economy, 1996) p. 4. Bell, Spurgeon, Productivity, Wages and National Income (Washington: Brookings Institution, 1940) p. 83. Woytinsky, Wladimir, Drei Ursachen der Arbeitslosigkeit (Geneva: International Labour Office, 1935) p. 165.

${ }^{72}$ Malthus, Thomas Robert, An Essay on Population, Vol. II (London: Dent \& Sons, 1958), pp. $57 \mathrm{ff}$.

${ }^{73}$ Elsenhans, Hartmut "English Poor Law and Egalitarian Agrarian Reform in the Third World", in Elsenhans, Hartmut, Equality and Development (Dhaka: Center for Social Studies, 1992), pp. 130-62.
} 
for a negative citizen tax, the least complicated mechanism of subsidizing labor with lower than subsistence earnings, are no different in their basic mode of operation than the English Poor Laws. Subsidies are used to complement low incomes due to market conditions and force the more productive sectors of the economy to pay the difference.

Industrial policy consists in the mobilization of resources in favor of branches which at the prevailing cost and price levels are not yet profitable, but where future profitability is expected due to the benefits of being first. ${ }^{74}$ There are few means to distinguish whether "inefficiency" is due to the premature character of the investment or to less acceptable forms of waste.

\section{PERSPECTIVES}

Globalization leads to serious underconsumption pressures because marginality-ridden catching-up economies are able to proceed to massive devaluation with implicit export subsidies. They are able to do so if there is a sufficient agricultural surplus and hence an element of productivity increase without any mechanisms for redistribution other than employment growth on the basis of cheap exports of manufactured products, which does not, however, lead to full employment. It seems highly improbable that the bulk of marginality-ridden countries can achieve full employment and eliminate marginality only on the basis of exports and without complementary internal reforms.

More advanced economies cannot cope with this challenge merely by lowering their real wages, and not even by increasing the spread of their wages. An end to the self-sufficiency of catching-up economies in food production, or an end to the competitiveness of technically leading economies in high-technology branches (via taxes on such exports ${ }^{75}$ ) are theoretical possibilities but not very realistic options. The dilemma of the leading industrial countries can therefore only be solved if the catching-up economies not only increase their sectorial competitiveness but also their marginal productivity. This would lead to larger internal markets, to the trickling down of productivity increases to all branches, and, in the case of undervalued currencies, to a massive export expansion and currency appreciation, finally, to the end of the devaluation-driven growth process. Japan, Taiwan and South Korea are today no longer low-cost-labor countries, because export-drives in these

\footnotetext{
${ }^{74}$ Krugman, Paul R. "Increasing Returns, Monopolistic Competition and International Trade”, in Journal of International Economics, 9, 4 (November 1979), pp. 469-79.

75 The advanced countries could tax their high-technology exports, which would result in a lower exchange rate, so that labor in their low-technology branches is internationally competitive. This would probably prove to be a rather difficult measure, facing considerable political opposition since these export sectors are considered the engine of growth in the economies of the West.
} 
countries led to the rapid expansion of internal mass markets and considerable currency appreciations in various phases.

These cases show that the main challenge is tackling the problem of marginality. Marginality, in reality, limits the effects of globalization; it is not the product of globalization, but existed long before. In order to increase the pull effects of demand that originate from the globalization process, the internal restrictions to the extension of multiplier and accelerator effects in these economies have to be removed. The implementation of such reforms, which I have described elsewhere, ${ }^{76}$ is assisted by further exports, as these allow managing agricultural surpluses without the burden of heavy administrative apparatuses. Export-led growth allows agricultural surpluses to be transformed into mass incomes without cumbersome planning agencies and a vast extension of the non-market economy. This aspect is important, as it seems that agricultural surpluses are more easily achieved than rises in the marginal productivity of agricultural labor due to the world demand structure for agricultural technology, which is dominated by the industrialized West.

It is not the globalization process which represents the challenge - apart from the fact that its intensity is too low - but the specific pattern it follows. As long as globalization is either indiscriminately welcomed or per se held responsible for the results which, in reality, it induces through its lack of intensity, the reforms necessary for making globalization work more effectively cannot be expected to find substantial support in the international community.

What we are observing at present - just as in the nineteenth century - is various social policies in favor of the South. These measures invariably concentrate on increasing the productivity of labor, since it is assumed that labor is unemployed because it is not productive enough. Entitlement is thus neglected. Productivity, however, is not per se employment creating, as demonstrated by the criticisms of the neoclassical argument. The neoclassical model functions as long as labor is empowered; if labor is not empowered, wages cannot rise to the level of marginal product. All empirical studies agree that an increase in real wages took place in the nineteenth century, namely, during economic crisis via rapidly falling prices, ${ }^{77}$ but,

\footnotetext{
${ }^{76}$ Elsenhans 1997, Relevance, art. cit., fn. 44, pp. 294-7.

77 Bernanke, Ben S.; Carey, Kevin "Nominal Wage Stickiness and Aggregate Supply in the Great Depression", in Quarterly Journal of Economics, 111, 3 (August 1996), p. 881. Hanes, Christopher "The Development of Nominal Wage Rigidity in the Late 19th Century", in American Economic Review, 83, 4 (September 1993), p. 745. Tucker, Rufus S. "Real Wages of Artisans in London, 1729-1935", in Journal of the American Statistical Association, 31, 1 (1936), pp. 83-4. Keynes, John Maynard "Relative Movements of Real Wages and Output", in Economic Journal, 49, 193 (March 1939), pp. 35-6. Richardson, Henry "Real Wage Movements", in Economic Journal, 49, 195 (September 1939), pp. 43141. Habakkuk, Hrothgar J. "Fluctuations and Growth in the 19th Century", in Robertson, H. M.; Kooy, M. (eds.) Studies in Economics and Economic History (London: Macmillan, 1972), p. 275. Rosenberg, Hans, Die Weltwirtschaftskrise von 1857-1859 (Stuttgart; Berlin: Kohlhammer, 1934), p. 185. Woytinsky, Wladimir, Les conséquences sociales de la crise (Geneva: International Labour Office, 1936), pp. 12735. Montgomery, Arthur, How Sweden Overcame the Depression (Stockholm: Alb. Bonniers Boktryckeri, 1938), p. 52. Rostow, Walt Whitman “Investment and the Great Depression”, in
} 
more importantly, that these conditions do not exist in the twentieth century. The challenge therefore does not consist in a massive restructuring of the world economy, which nobody is ready to engage in because of the sheer size of the task. The challenge is much more simple: to remove the fetters on large-scale productivity growth in poor countries by combating marginality for a transitional period, thus making the world safe for market regulation.

Economic History Review, 8, 2 (May 1938), pp. 136-58. Mieczkowski, Bogdan "Estimates of Changes in Real Wages in Poland During the 1960s", in Slavic Review, 31, 3 (September 1972), pp. 651-6. 